\title{
Seed quality of 22 quinoa materials (Chenopodium quinoa Willd.) from the department of Boyacá ${ }^{1}$
}

\author{
Elsa Helena Manjarres Hernández ${ }^{2}$, Ana Cruz Morillo Coronado ${ }^{*} \mathbb{D}$, Wendy Lorena Reyes Ardila ${ }^{2}$
}

10.1590/0034-737X202067040008

\begin{abstract}
Chenopodium quinoa Willd. is a pseudocereal with seeds that are a rich source of vitamins and minerals. However, there are few studies on quinoa seed quality, especially for the Colombian germplasm. So, the objective of this research was to determine the quality of 22 quinoa materials from the Department of Boyacá by evaluating the physical (color, shape and diameter) and physiological (tetrazolium test) quality of the seeds. It was found that $36 \%$ of the materials had a white grain color, $80 \%$ cylindrical shape, $65 \%$ smooth edges and diameters smaller than $2 \mathrm{~mm}$, desirable characteristics for post-harvest processes. The evaluated physical characteristics presented high variability between the evaluated materials, which is desirable for elite breeding processes. The imbibition rate showed that germination was rapid (at 4 hours, the weight of the seeds doubled), that is, the materials were not dormant. Finally, it was determined that storage conditions, such as temperature and relative humidity, are essential for preventing deterioration in quinoa seeds; these factors can also affect germination and long-term vigor.
\end{abstract}

Keywords: cereal; germination; vigor; viability.

\section{INTRODUCTION}

Quinoa (Chenopodium quinoa Willd.) is an Andean ancestral crop that belongs to the Amarantaceae family and has great nutritional value and broad agroecological adaptation (Razzaghi et al., 2015), with resistance to biotic and abiotic factors (Hussin et al., 2017). Its seeds are rich in minerals, including phosphorus, calcium, sodium, potassium, iron, zinc, manganese and copper, fiber and vitamins, along with a high antioxidant capacity (Valencia et al., 2017). Therefore, quinoa has been considered in the search for solutions to food shortages worldwide (Bazile et al., 2015).

Quinoa seeds have been described as flat and spherical with an average diameter between 1.4-1.6 mm (Abugoch, 2009), where the endosperm appears as a cap that surrounds the radicle. Starch is found exclusively in the perisperm, while proteins and lipids are in the embryo (Prego et al., 1998). The same structure can be observed in the sugar beet (Abbasi et al., 2018) and amaranth seeds (Ye and Wen, 2017). The high protein content of quinoa is due to the fact that $60 \%$ of the seed weight corresponds to the embryo that has a hypocotyl-radicle axis and two cotyledons. In the micropillary region of the seed is present the endosperm with one or two layers of tissue that surround the tip of the radicle (Gomaa et al., 2014). Once the saponins are removed from the pericarp of the seeds, quinoa can be used for different products, such as flour production (Abderrahim et al., 2015). Quinoa is suitable for people on a gluten-free diet, which is beneficial for human health (Vilcacundo et al., 2017).

Due to its composition of starches and lipids, quinoa seed has greater storage stability than other oilseeds (Filho, 2015). Because its seeds have pores in the integument, which facilitate the gain or loss of moisture, they lose viability faster (Spehar, 2007). The quality of the quinoa seed is influenced by the low percentage of germination and the reduction of vigor (Kappes et al., 2012), affecting its longevity. The quality of the seed is determined by its

\footnotetext{
Submitted on December $23^{\text {th }}, 2019$ and accepted on June $22^{\text {nd }}, 2020$.

${ }^{1}$ This work is part of the first author's Doctoral Dissertation.

${ }^{2}$ Universidad Pedagógica y Tecnológica de Colombia, Facultad Ciencias Agropecuarias, Tunja, Boyacá, Colombia. elsa.manjarres@uptc.edu.co; ana.morillo@uptc.edu.co; wendy.reyes@uptc.edu.co

* Corresponding author: ana.morillo@uptc.edu.co
}

Rev. Ceres, Viçosa, v. 67, n.4, p. 306-314, jul/aug, 2020 
genetic, physical, physiological and health attributes that determine its yield potential (Santos et al., 2007). On the other hand, germination is influenced by intrinsic and extrinsic factors such as temperature, relative humidity, oxygen, and the action of fungi and bacteria (Filho, 2015). Seed germination is regulated by physiological factors and environmental conditions, since each species has specific germination requirements such as water availability, temperature, light, and planting depth (Filho, 2015).

In seed analysis, vigor tests have been used primarily to identify differences in seed batch yield during storage and after planting in order to highlight more effective batches for establishment under a wide range of environmental conditions. Germination tests evaluate physiological quality, but the results are not always correlated with emergence in the field, as well as germination rate indices and emergence potential as parameters of vigor; in order to determine the seed yield and the speed of development of normal seedlings under various environmental conditions (Filho, 2015).

Seed quality has a direct impact on productivity, but research on quinoa seeds is just beginning. Gomaa et al. (2014) conducted studies on the micro-macromorphological and anatomical characteristics of quinoa (C. quinoa), where he described the structural and functional aspects of the seeds. Mäkinen et al. (2014) studied the development of proteolytic activities and protein profiles in C. quinoa seeds during germination and early growth, where the endosperm has 60 times more proteolytic activity than the embryo, weakening the endosperm during germination. On the other hand, Hager et al. (2014) researched amylolytic activities and mobilization of starch reserves during germination in quinoa. In general, the activity levels remained very low, suggesting that these seeds are not a source of amylases.

Several studies have been carried out to determine the physical characteristics, phenolic components and antioxidant capacity of quinoa seeds because of their high nutritional value and their effect on human health (Valencia et al., 2017; Vilcacundo et al., 2017), and it has also been determined that, in the Chenopodium genus, there is embryonic latency, for which the seed covers are largely responsible, that is greatly affected by the environmental conditions of seed development (Ceccato et al., 2015; Strenske et al., 2017). Recent studies have evaluated the effect of different environments, such as saline conditions, and phytosanitary quality on germination, vigor, and number of normal plants, among other parameters (A1Barakah and Sohaig, 2019; El-Assiuty et al., 2019), showing that the physical, genetic, physiological and sanitary quality of seeds are a fundamental requirement for maintaining productivity and that quinoa seeds, like other seeds, need specific conditions to germinate and maintain vigor. Taking into account the expanding cultivation area for quinoa, the growing popularity of grain in domestic and foreign markets, and the lack of scientific information on seed quality, this study aimed to assess the influence of the storage conditions of the Boyacá quinoa germplasm bank on the viability and vigor of its quinoa seeds.

\section{MATERIAL AND METHODS}

The 22 materials stored in the quinoa seed collection of the Laboratory de Biotechnology Vegetal of Secretary of Agricultural Development of the Government of Boyacá from municipalities in the Department of Boyacá were evaluated: Duitama, Tibasosa, Siachoque, Tunja, Soracá, Tuta, Cerinza, Combita, Beteitiva and Sotaquirá. Three materials were collected directly from farmers in the municipalities of Tunja, Tibasosa and Siachoque (Table 1). The physical and physiological characterization of the seeds was carried out in the Plant Physiology Laboratory and the Plant Molecular Biology Laboratory of the Pedagogical and Technological University of Colombia, in Tunja, with the geographical coordinates $5^{\circ} 332163 \mathrm{~N}$ and $73^{\circ} 212093 \mathrm{~W}$.

To determine the physical quality of the seeds, 20 seeds of each material were evaluated with the help of a stereoscope. The studied parameters included color, shape and diameter of the seeds. The weight was determined with 100 seeds for each material in triplicate, the moisture content was established with the fresh weight of 100 seeds and, after drying in an oven at $80{ }^{\circ} \mathrm{C}$ for 8 hours, the dry weight was measured.

$\%$ Moisture $=\frac{m^{1}-m^{2}}{m^{2}} \times 100$

Where: $m^{1}$ is the fresh weight of 100 seeds $(\mathrm{g}) \cdot \mathrm{m}^{2}$ is the dry weight of 100 seeds.

For the imbibition rate, an initial weight of $10 \mathrm{~g}$ of seeds and two repetitions per sample were taken. Each sample was placed in distilled water, and, at intervals of one hour, the weight gain of the seeds was recorded. The readings were taken until the weight of the samples stabilized or the variation between the samples had narrow values (Moreno et al., 2006).

The viability of the seeds was evaluated with a biochemical tetrazolium test, for which 100 seeds were taken from each sample and placed in the solution at a concentration of $1 \%$. The intensity of coloration (red) was then read.

The germination tests were carried out in vitro with petri dishes and filter paper; for this, 25 seeds were taken from each material, with three repetitions. After 12 hours, the germinated seed data were recorded for 120 hours, with the germinated criterion being seeds that have a radicle of about $2 \mathrm{~mm}$ emerged. 


\begin{tabular}{|c|c|c|c|c|c|}
\hline Material code & Bank code & Place of collection & Storage time (years) & Georeferencing & Variety or common name \\
\hline 1 & BGQ0009 & Ventaquemada & 7 & $5^{\circ} 22^{\prime} 00.4^{\prime \prime N} 73^{\circ} 31^{\prime} 16.9^{\prime \prime} \mathrm{W}$ & Quinua real \\
\hline 2 & BGQ0011 & Soracá & 1 & $5^{\circ} 30^{\prime} 06.9^{\prime \prime} \mathrm{N} 73^{\circ} 20^{\prime} 00.5^{\prime \prime} \mathrm{W}$ & Aurora \\
\hline 3 & BGQ0012 & La colorada Tunja & 3 & $5^{\circ} 34^{\prime} 44.7^{\prime \prime} \mathrm{N} 73^{\circ} 20^{\prime} 36.0^{\prime \prime} \mathrm{W}$ & Ceniza \\
\hline 4 & BGQ0013 & Beteitiva & 4 & $5^{\circ} 54^{\prime} 39.1^{\prime \prime} \mathrm{N} 72^{\circ} 48^{\prime} 31.2^{\prime \prime} \mathrm{W}$ & \\
\hline 5 & BGQ0015 & Sotaquira. Vereda Bociga & 5 & $5^{\circ} 45^{\prime} 57.6^{\prime \prime N} 73^{\circ} 14^{\prime} 52.2^{\prime \prime} \mathrm{W}$ & \\
\hline 6 & BGQ0017 & La colorada Tunja & 1 & $5^{\circ} 34^{\prime} 44.7^{\prime \prime} \mathrm{N} 73^{\circ} 20^{\prime} 36.0^{\prime \prime} \mathrm{W}$ & Quinua negra \\
\hline 7 & BGQ0018 & ICA Surbata & 21 & $5^{\circ} 47^{\prime} 45.5^{\prime \prime} \mathrm{N} 73^{\circ} 04^{\prime} 20.2^{\prime \prime} \mathrm{W}$ & Tunkahuan \\
\hline 8 & BGQ0019 & Tuta & 3 & $5^{\circ} 41^{\prime} 26.6^{\prime \prime N} 73^{\circ} 13^{\prime} 39.1^{\prime \prime W}$ & Blanca de Jericó \\
\hline 9 & BGQ0020 & Pasca & 9 & $4^{\circ} 18^{\prime} 32.8^{\prime \prime} \mathrm{N} 74^{\circ} 17^{\prime} 59.6^{\prime \prime} \mathrm{W}$ & Amarilla de Marangani \\
\hline 10 & BGQ0022 & La colorada Tunja & 2 & $5^{\circ} 34^{\prime} 44.7^{\prime \prime} \mathrm{N} 73^{\circ} 20^{\prime} 36.0^{\prime \prime} \mathrm{W}$ & \\
\hline 11 & BGQ0024 & Soracá & 4 & $5^{\circ} 30^{\prime} 06.9^{\prime \prime} \mathrm{N} 73^{\circ} 20^{\prime} 00.5^{\prime \prime} \mathrm{W}$ & Blanca dulce de Soracá \\
\hline 12 & BGQ0025 & Choconta & 4 & $5^{\circ} 08^{\prime} 44.3^{\prime \prime} \mathrm{N} 73^{\circ} 41^{\prime} 07.0^{\prime \prime} \mathrm{W}$ & Piartal \\
\hline 13 & BGQ0027 & Centro de Diagnóstico Agropecuario & 5 & $5^{\circ} 33^{\prime} 13.8^{\prime \prime N ~} 73^{\circ} 21^{\prime} 37.1^{\prime \prime} \mathrm{W}$ & \\
\hline 14 & BGQ0028 & Tuta & 3 & $5^{\circ} 41^{\prime} 26.6^{\prime \prime} \mathrm{N} 73^{\circ} 13^{\prime} 39.1^{\prime \prime} \mathrm{W}$ & Quinua dulce de Tuta \\
\hline 15 & BGQ0029 & Duitama & 6 & $5^{\circ} 49^{\prime} 36.3^{\prime \prime} \mathrm{N} 73^{\circ} 02^{\prime} 03.9^{\prime \prime} \mathrm{W}$ & Quinua semiamarga \\
\hline 16 & BGQ0032 & Combita & 3 & $5^{\circ} 38^{\prime} 01.9^{\prime \prime} \mathrm{N} 73^{\circ} 19^{\prime} 28.4^{\prime \prime} \mathrm{W}$ & Peruana \\
\hline 17 & BGQ0034 & Siachoque & 5 & $5^{\circ} 30^{\prime} 45.3^{\prime \prime} \mathrm{N} 73^{\circ} 14^{\prime} 44.3^{\prime \prime} \mathrm{W}$ & \\
\hline 18 & BGQ0035 & Pasca & 9 & $4^{\circ} 18^{\prime} 32.8^{\prime \prime} \mathrm{N} 74^{\circ} 17^{\prime} 59.6^{\prime \prime} \mathrm{W}$ & Posible Piartal \\
\hline 19 & BGQ00101 & Centro de Diagnóstico Agropecuario & 1 & $5^{\circ} 33^{\prime} 13.8^{\prime \prime} \mathrm{N} 73^{\circ} 21^{\prime} 37.1^{\prime \prime} \mathrm{W}$ & Dorada \\
\hline 20 & CQ001 & Tuta & 1 & $5^{\circ} 41^{\prime} 26.6^{\prime \prime} \mathrm{N} 73^{\circ} 13^{\prime} 39.1^{\prime \prime} \mathrm{W}$ & Blanca de Jericó \\
\hline 21 & CQ002 & Tibasosa & 1 & $5^{\circ} 44^{\prime} 40^{\prime \prime} \mathrm{N} 73^{\circ} 14^{\prime} 16^{\prime \prime} \mathrm{W}$ & Piartal \\
\hline 22 & CQ003 & Tunja & 1 & $5^{\circ} 31^{\prime} 4^{\prime \prime N} 73^{\circ} 23^{\prime} 48^{\prime \prime W}$ & Blanca de Jericó \\
\hline
\end{tabular}


For the germination speed, daily germination percentage readings were taken for five days to determine the average number of seeds germinated per day, using the formula proposed by Maguire (1962):

$V e l G=\sum_{i=1}^{n} \frac{x i}{n}$

Where: $x i=$ Number of germinated per day. $n=$ Number of days that passed after sowing.

\section{RESULTS AND DISCUSSION}

The results showed that, for the variable grain color in the evaluated materials, the color white predominated, followed by a light brown color (Figure 1), which favors quality in this parameter. In addition, the commercialization of quinoa prefers grain that is white, large and clean, with low saponin contents. Determining seed quality is essential to conservation and commercial management, ensuring germination capacity, rapid emergence, uniformity and, thus, good crop establishment (Ceccato et al., 2015). Therefore, factors, such as the physical, chemical and physiological quality of seeds, must be controlled. Within quinoa, two large groups are recognized: cultivated quinoa, which is characterized by seeds that are clear with thin and translucent testae, and wild quinoa with dark seeds and dense testae (Fuentes and Bhargava, 2011). However, although the processes of domestication of quinoa crops reduced their genetic diversity, the phenotypic diversity of cultivated quinoa at the seed level remains broad.

The descriptors proposed by International Biodiversity for quinoa and its wild relatives include seed shape: lenticular, cylindrical, ellipsoidal and conical; however, in this study, it was found that, in addition to these shapes, there are different types of seed edges, as can be seen in Figure 1, where some evaluated materials presented smooth, sinuous or wavy edges. Likewise, variation in seed color was observed, ranging from black, yellow, white and beige, $36 \%$ being white; $80 \%$ of the materials were cylindrical and $65 \%$ were smooth (Table 2).

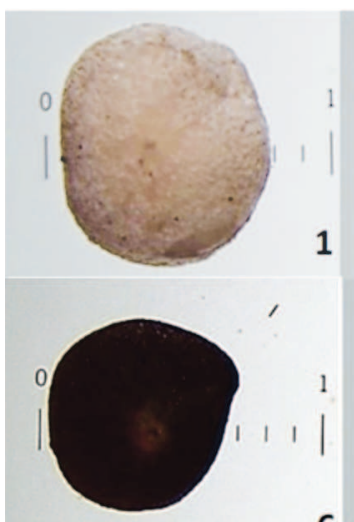

6

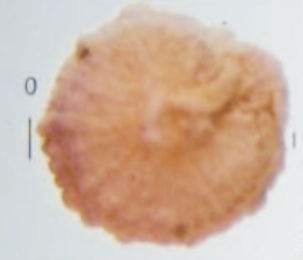

2

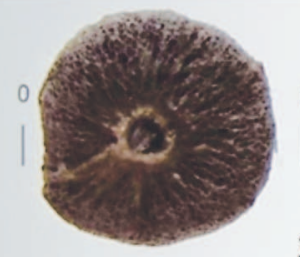

3

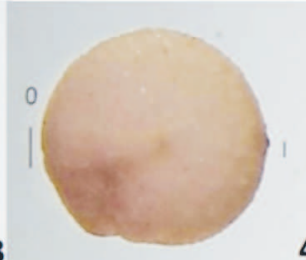

4
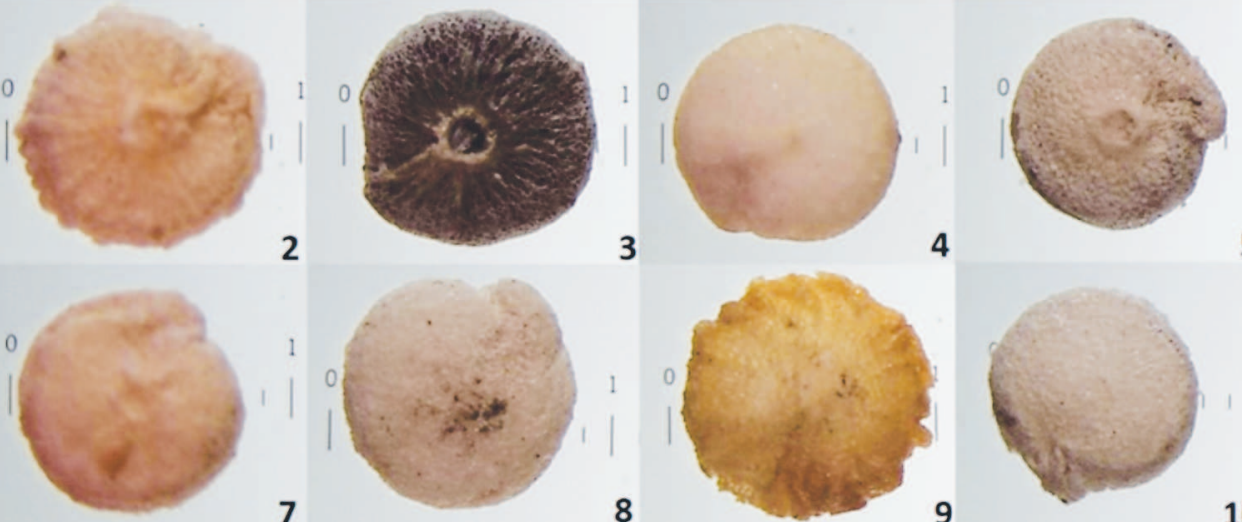

7

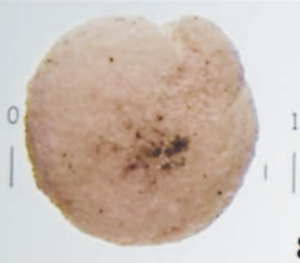

8

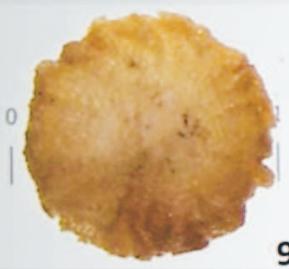

9

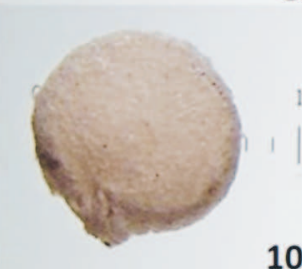

10

12

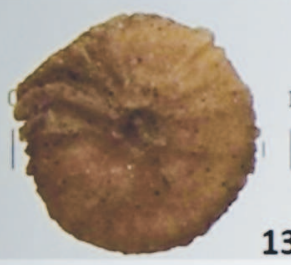

13

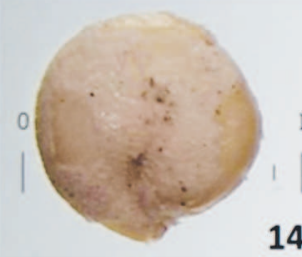

14

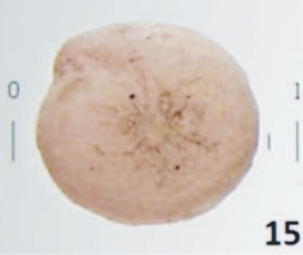

15

17
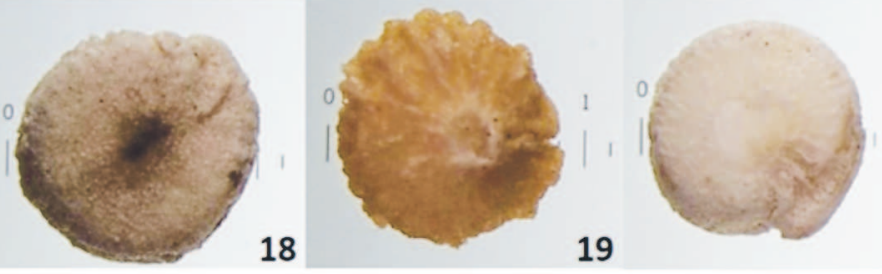

20
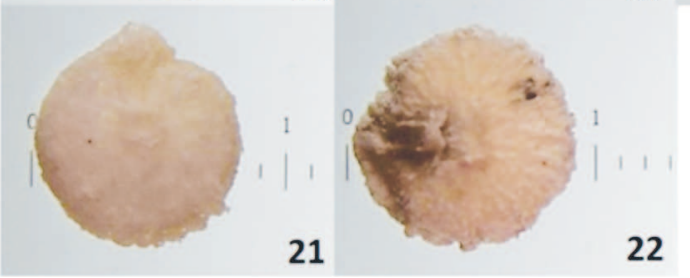

Figure 1: Photographs of quinoa seeds of the materials present in the Department of Boyacá. 
In Colombia, there are no certified or selected quinoa seed, meaning crops have high variability in color and size in seeds and plants in general (Morillo et al., 2017). On the other hand, for the commercialization of quinoa, the physical characterization of the grains is vital because it is necessary to adapt the technologies associated with postharvest, cleaning, separation and classification of the seeds, leading to acceptance in the market when used in conjunction with existing quality standards and consumer preference, such as: grains that are $\geq 2 \mathrm{~mm}$, clean, white and free of saponins.

This study showed that the diameters of the seeds of the evaluated materials were less than $2 \mathrm{~mm}$ and that there was a correlation between the weight of the seeds and their diameter, which are important in postharvest processes because they aid the design of threshing machinery and the sorting and deponification of quinoa materials from the Department of Boyacá (Figure 2).

The germination of the seeds has three stages that can vary or overlap according to each species. The first stage is imbibition, a process in which seeds absorb water as a result of differences between the water potential (matrix) in the seeds and the imbibition solution, thereby hydrating the reserve tissue (Moreno et al., 2006). In the second stage, water absorption is decreased, initiating the metabolic reactions necessary for seedling growth. In the last stage, there is growth that is associated with the emergence of the radicle, along with an increase in metabolic activity and new water absorption activity.

Quinoa seeds do not present germination problems when they are properly stored: $4{ }^{\circ} \mathrm{C}$ and humidity percentages lower than $10 \%$. In this study, the imbibition curves showed that the germination rates were fast because, at 4 hours, the weight of the seeds doubled, promoting the metabolic processes for seedling growth (Figure 3). In studies conducted by Parsons (2012), it was also observed that most of the seeds formed a radicle 6-10 hours after imbibition. Very fast germination $(<24 \mathrm{~h})$ is a characteristic found in some seeds in high stress habitats, most of which belong to the Chenopodiaceae family, which can be an important survival characteristic (Parsons, 2012).

In grains, such as quinoa, moisture percentage is essential to prolonging shelf-life for conservation or commercialization. Grains that are subjected to drying can achieve a humidity of approximately $12 \%$. In this case, the materials conserved in the germplasm bank have between 8 and $13 \%$ moisture, while some commercialized grains have between 10 and $16 \%$ moisture. Studies have shown that quinoa seeds dried to $5-10 \%$ moisture remain viable (Ceccato et al., 2015). Because the studied materials were in storage for conservation purposes, the moisture percentages were between 8 and $13 \%$, which are adequate because quinoa grains are hygroscopic, making them susceptible to increased humidity. Therefore, it is vital to control humidity during storage (Figure 4).

Table 2: Shape, color and border of the seeds of quinoa materials

\begin{tabular}{lccc}
\hline Material & Shape & Color & Border \\
\hline 1 & Lenticular & Cream & Smooth \\
2 & Cylindrical & White & Sinuate \\
3 & Cylindrical & Light-dark brown blend & Smooth \\
4 & Cylindrical & Cream & Smooth \\
5 & Cylindrical & Light brown & Smooth \\
6 & Ellipsoidal & Black & Smooth \\
7 & Cylindrical & White & Smooth \\
8 & Cylindrical & Cream & Smooth \\
9 & Ellipsoidal & Orange & Sinuate \\
10 & Cylindrical & White & Smooth \\
11 & Cylindrical & White & Sinuate \\
12 & Cylindrical & White & Smooth \\
13 & Cylindrical & Light brown & Sinuate \\
14 & Cylindrical & Cream & Smooth \\
15 & Lenticular & Cream & Smooth \\
16 & Ellipsoidal & Orange-Yellow & Sinuate \\
17 & Cylindrical & Cream & Smooth \\
18 & Cylindrical & Cream & Smooth \\
19 & Cylindrical & Yellow & Sinuate \\
20 & Cylindrical & White & Smooth \\
21 & Cylindrical & White & Sinuate \\
22 & Cylindrical & White & Sinuate
\end{tabular}


The quinoa seeds preserved at $4{ }^{\circ} \mathrm{C}$ and 10 to $12 \%$ relative humidity presented germination percentages of 90 to $100 \%$ from 24 to 96 hours; however, the materials that were not kept at low temperatures, as farmers do, lost germination capacity, as seen in materials 6, 13, 18 and 20 (Table 3). Studies conducted by Souza et al. (2017) found that more than $80 \%$ of the evaluated quinoa seeds germinated at 20 to $30{ }^{\circ} \mathrm{C}$ with a 7-hour photoperiod and only $60 \%$ of the water retention capacity. Other factors, such as saline environments, also affect germination; however, they can contribute to increased concentration of antioxidants in seeds (Al-Barakah and Sohaib, 2019). Identifying the morphological and physiological processes that control dormancy in quinoa seeds and how they are affected by the environment is of great importance for the genetic improvement of this species. In this sense, Ceccato et al. (2015) suggested that embryonic latency is present in the Chenopodium genus and that the seed cover is largely responsible for this process. In addition, high temperatures and long photoperiods increase the cover and decrease the embryonic latency.

Germination is a process that is influenced by internal and external factors. The internal factors include viability, which can be measured with the biochemical tetrazolium test, which consists of the differentiation of living tissues. In this case, materials $6,13,18$ and 19 , which did not germinate, were tested, evidencing that the storage and conservation conditions directly generated damage on the

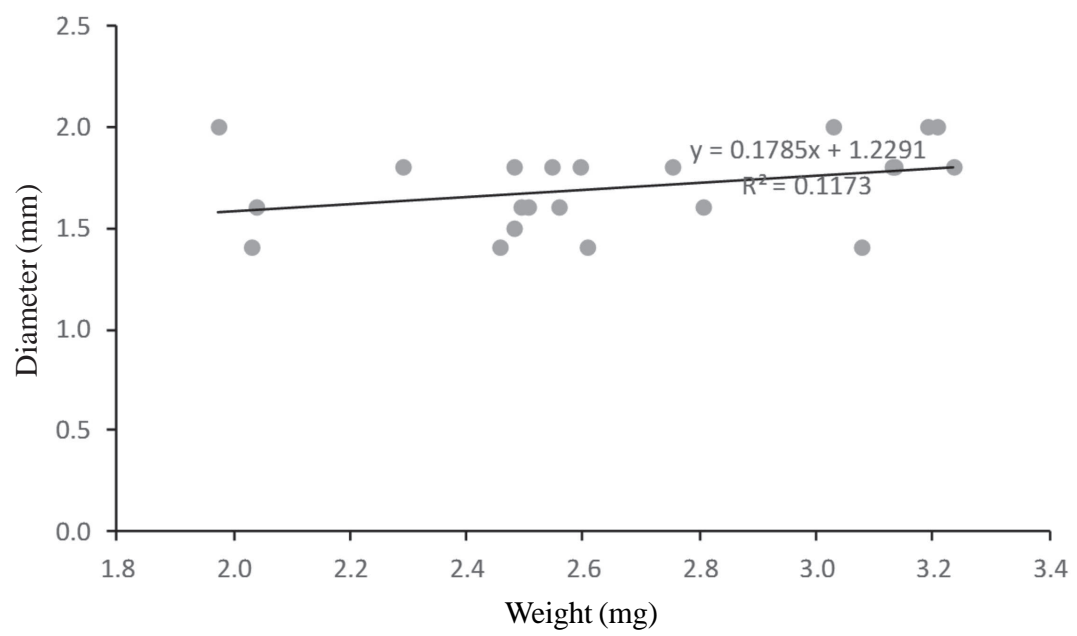

Figure 2: Relationship between the diameter $(\mathrm{mm})$ and the weight of the 1000 seeds of quinoa.

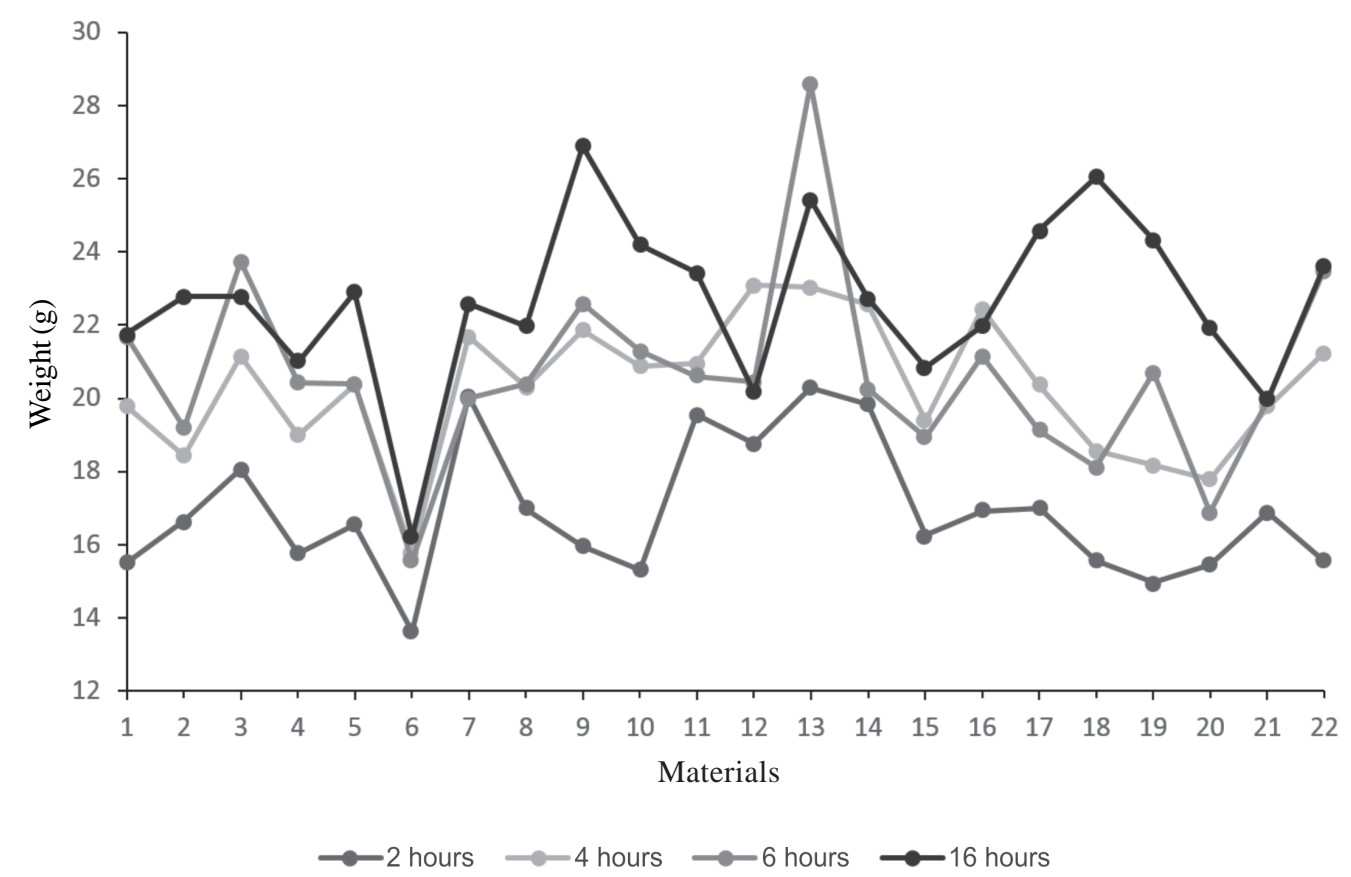

Figure 3: Relationship between the weight and time evaluated in the 22 quinoa materials studied. 


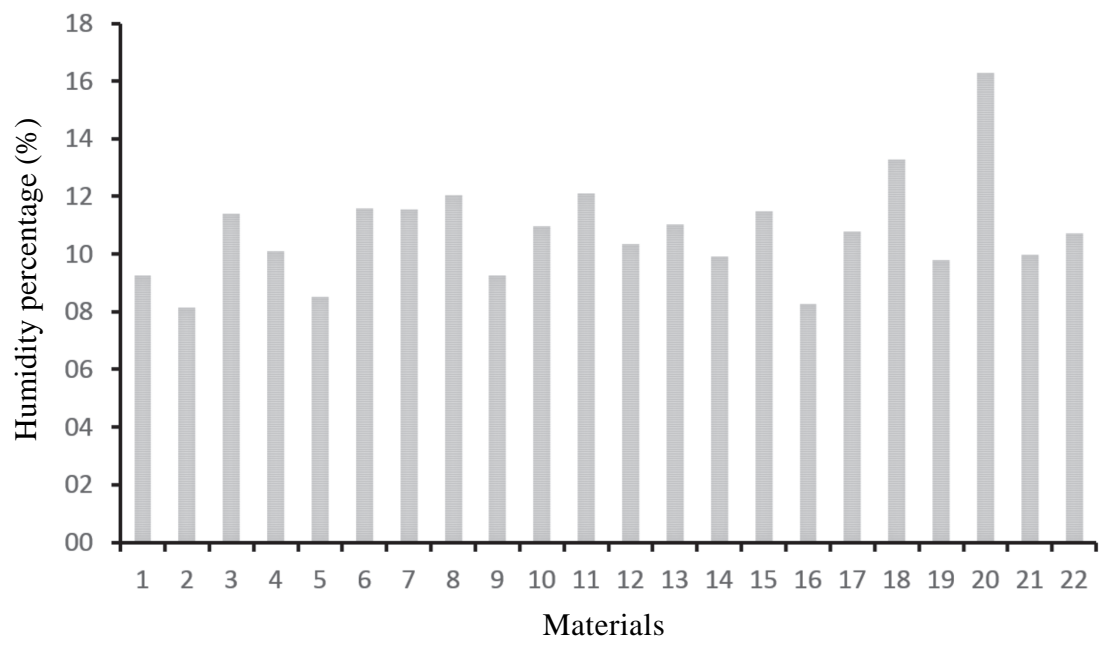

Figure 4: Moisture percentage in quinoa materials evaluated.

viability of the embryos for initiating germination processes (Figure 5).

Strenske et al. (2017) evaluated the germination and vigor of quinoa seeds wrapped in paper bags and stored at temperatures of 20, 30 and a constant temperature of 25 ${ }^{\circ} \mathrm{C}$; the seeds were subjected to seven-hour photoperiods and $25^{\circ} \mathrm{C}$ under continuous darkness for $36,85,119,146$, 177 and 270 days. The increase in storage time decreased the percentage of germinated seeds and their vigor as a result of the greater number of abnormal seedlings. During the 430 day study period, the germination of the quinoa seeds under the experiment conditions decreased. Therefore, the final number of germinated seeds should be evaluated seven days after the start of the germination test. Similar results were obtained by Nobre et al. (2013) who observed that amaranth seeds showed maximum germination and vigor to the point of physiological maturity and then began to decrease.

Storage temperature and relative humidity are the principal factors that affect the physiological quality of seeds. Strenske et al., (2017) observed that the germination of the stored quinoa seeds was maintained under controlled environmental conditions, since if the temperature and humidity were not controlled in storage, the germination of the seeds decreases.

Filho (2015) stated that seeds deteriorate when they are exposed to long storage periods under uncontrolled conditions. However, these mechanisms have not been fully elucidated, so the deterioration has been attributed to the genetic factors of the seed. Furthermore, temperature control such as relative humidity under storage conditions can minimize seed deterioration. At the biological level, deterioration is related to loss of membrane integrity, decreased selective capacity, lipid oxidation, solute leaching, changes in enzyme, transpiration, and protein synthesis in seeds (Filho, 2015).
Finally, it was observed that, during long storage periods under ambient conditions, the quality of quinoa seeds deteriorates and that environmental factors such as temperature and relative humidity must be controlled in order to prevent the germination and vigor of the seeds from rapidly decreasing.

\section{CONCLUSIONS}

The evaluated quinoa materials displayed phenotypic variability for the color of the seeds and of the grains. It

Table 3: Germination percentage at 24, 28, 72 and 96 hours in the 22 quinoa materials evaluated

\begin{tabular}{lrrrr}
\hline Materials & \% G24 & \%G48 & \%G72 & \%G96 \\
\hline 1 & 73 & 92 & 97 & 100 \\
2 & 95 & 99 & 100 & \\
3 & 93 & 96 & 100 & \\
4 & 36 & 76 & 92 & 96 \\
5 & 64 & 75 & 84 & 85 \\
6 & 0 & 0 & 0 & 5 \\
7 & 83 & 95 & 96 & 97 \\
8 & 76 & 91 & 95 & 96 \\
9 & 89 & 92 & 99 & 100 \\
10 & 8 & 40 & 69 & 81 \\
11 & 76 & 96 & 96 & 97 \\
12 & 91 & 96 & 100 & \\
13 & 0 & 0 & 0 & 0 \\
14 & 63 & 73 & 80 & 88 \\
15 & 35 & 65 & 84 & 91 \\
16 & 99 & 100 & & \\
17 & 77 & 93 & 99 & 100 \\
18 & 0 & 0 & 0 & 0 \\
19 & 0 & 0 & 0 & 0 \\
20 & 100 & & & \\
21 & 100 & & & \\
22 & 76 & 91 & 95 & 97 \\
\hline
\end{tabular}




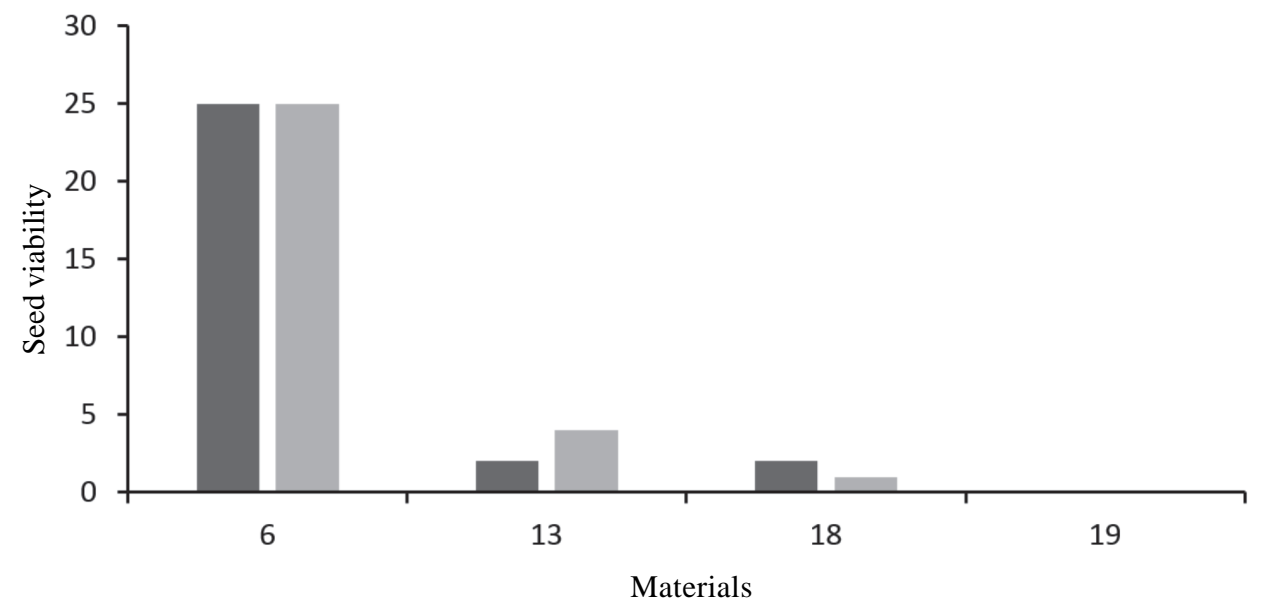

Figure 5: Viability of the seeds of materials 6, 13, 18 and 19.

was determined that environmental conditions play a very important role in seed quality parameters, such as germination and vigor, and that storage temperature and humidity can delay or decrease the physiological deterioration of quinoa seeds.

\section{ACKNOWLEDGEMENTS AND FINANCIAL SUPPORT}

The authors would like to thank the "Patrimonio Autónomo Fondo Nacional de Financiamiento para la Ciencia, la Tecnología y la Innovación Francisco José de Caldas- MinCiencias. Cód. 63924”.

\section{CONFLICT OF INTEREST}

The authors declare no financial or other competing conflicts of interest.

\section{REFERENCES}

Abbasi Z, Golabadi M, Khayamin S \& Pessarakli M (2018) The response of drought-tolerant sugar beet to salinity stress under field and controlled environmental conditions. Journal of Plant Nutrition, 41:2660-2672.

Abderrahim F, Huantico E, Segura R, Arribas S, Gonzalez C \& Condezo L (2015) Physical features phenolic compounds, betalains and total antioxidant capacity of coloured quinoa seeds (Chenopodium quinoa Willd.) from Peruvian Altiplano. Food Chemistry, 183:83-90.

Abugoch J (2009) Quinoa (Chenopodium quinoa Willd.): Composition, chemistry, nutritional, and functional properties. Advances in Food and Nutrition Research, 58:01-31.

Al-Barakah F \& Sohaib M (2019) Evaluation the germination response of Chenopodium quinoa seeds to bacterial inoculation under different germination media and salinity conditions. Seed Science and Technology, 47:161-169.

Bazile D, Bertero HD \& Nieto C (2015) State of the Art Report on Quinoa around the World in 2013. Rome, FAO/CIRAD. 589 p.
Ceccato D, Bertero D, Batlla D \& Galati B (2015) Structural aspects of dormancy in quinoa (Chenopodium quinoa): importance and possible action mechanisms of the seed coat. Seed Science Research, 01:01-09.

El-Assiuty E, Taha E, Fahmy Z \& Fahmy G (2019) Histological and molecular detections of Peronospora variabilis Gäum oospores in seeds of quinoa (Chenopodium quinoa L.). The Egyptian Society of Experimental Biology, 15:197-203.

Filho M (2015) Fisiología de sementes de plantas cultivadas. $2^{a}$ ed. Londrina, Abrates. p. 58-76.

Fuentes F \& Bhargava A (2011) Morphological analysis of Quinoa germplasm grown under lowland desert conditions. Journal of Agronomy and Crop Science, 197:124-134.

Gomaa E (2014) Studies on some micro-macromorphological and anatomical characters of quinoa (Chenopodium quinoa Willd.) Plant. Research Journal of Agriculture and Biological Sciences, 10:24-36.

Hager A, Taylor J, Deborah W \& Elke A (2014) Gluten free BeerA review. Trends in Food Science \& Tecnology, 36:44-54.

Hussin S, Khalifa W, Geissler N \& Koyro HW (2017) Influence of the root endophyte Piriformospora indica on the plant water relations, gas exchange and growth of Chenopodium quinoa at limited water availability. Journal of Agronomy and Crop Science, 203:373-384.

Kappes C, Arf O, Ferreira JP, Portugal JR, Alcalde M, Arf M \& Vilela RG (2012) Qualidade fisiológica de sementes e crescimento de plântulas de feijoeiro, em função de aplicações de paraquat em précolheita. Pesquisa Agropecuária Tropical, 42:09-18.

Maguire JD (1962) Speed of germination-aid selection and evaluation for seedling emergence and vigor. Crop Science, 2:176-177.

Mäkinen O, Hager A \& Arendt E (2014) Localisation and development of proteolytic activities in quinoa (Chenopodium quinoa) seeds during germination and early seedling growth. Journal of Cereal Science, 60:484-489.

Moreno F, Plaza P \& Magnitskiy S (2006) Efecto de la testa sobre la germinación de semillas de caucho (Hevea brasiliensis Muell.). Agronomía Colombia, 24:290-295.

Morillo A, Castro M \& Morillo Y (2017) Caracterización de la diversidad genética de una colección de quinua (Chenopodium quinoa Willd). Biotecnología en el Sector Agropecuario y Agroindustrial, 15:49-56. 
Nobre DAC, David AMSS, Souza V, Oliveira D, Gomes AAM, Aguiar PM \& Mota W (2013) Influência do ambiente de armazenamento na qualidade fisiológica de sementes de amaranto. Comunicata Scientiae, 04:216-219.

Parsons RF (2012) Incidence and ecology of very fast germination. Seed Science Research, 22:161-167.

Prego I, Maldonado S \& Otegui R (1998) Seed structure and localization of reserves in Chenopodium quinoa. Annals of Botany, 82:481-488.

Razzaghi F, Jacobsen S, Jensen C \& Neumann A (2015) Ionic and photosynthetic homeostasis in quinoa challenged by salinity and drought-mechanism of tolerance. Functional Plant Biology, 42:136-148.

Santos E, Póla JN, Barros A \& Prete C (2007) Qualidade fisiológica e composição química das sementes de soja com variação na cor do tegumento. Revista Brasileira de Sementes, 29:20-26.

Souza F, De Souza J, Souza N, Sephar C \& De Jesus T (2017) Standardizing germination tests for quinoa seeds. African Journal of Agricultural Research, 12:155-160.
Spehar C (2007) Quinoa: alternative para diversificação agrícola e alimentar. Planaltina, Embrapa Cerrados. p. 86-94.

Strenske A, Vasconcelos E, Egewarth, Michelon N \& Malavasi M (2017) Responses of quinoa (Chenopodium quinoa Willd.) seeds stored under different germination temperatures. Acta Scientiarum, 39:83-88.

Valencia Z, Cámara F, Ccapa K, Catacora P \& Quispe F (2017) Compuestos bioactivos y actividad antioxidante de semillas de quinua peruana (Chenopodium quinoa W.). Revista Sociedad Química del Perú, 83:16-29.

Vilcacundo R \& Hernández B (2017) Nutritional and biological value of quinoa (Chenopodium quinoa Willd.). Currrent Opinion in Food Science, 14:01-06.

Ye J \& Wen B (2017) Seed germination in relation to the invasiveness in spiny amaranth and edible amaranth in Xishuangbanna, SW China. Plos One, 12:01-15. 